\title{
TINJAUAN HUKUM PIDANA ISLAM TERHADAP PASAL 6-19 UNDANG-UNDANG NOMOR 15 TAHUN 2003 TENTANG PEMBERANTASAN TINDAK PIDANA TERORISME
}

\author{
Huzaimah Al-Anshori \\ Fakultas Hukum Universitas Islam Kadiri (UNISKA) \\ Jalan Sersan Suharmaji No.38 Kediri, Jawa Timur, Indonesia
}

\begin{abstract}
The violations of Terrorism foreseen by Act 15 of 2003 is all acts that contain the elements offenses which are in the legislation. Criminal elements contained in chapter III is quite diverse, but the author classifies criminal elements into six terms from other forms of criminal acts. 1. Intentionally using violence or the threat of criminalvictim. 2. Criminal relating to force.3. Used weapons or other dangerous tools are meant.4. Mean to provide or collect funds for the implementation of acts of terrorism. 5. Mean to provide help, assistance, convenience, facilities or information for criminal acts of terrorism.6. Consensus of criminals, experiment, plan and / or mobilize others. Plot, experiment. Viewed from the standpoint of Islamic criminal law, six forms of criminal act here have much in common with the jarimah qat'al-tariq compared with jarimah-jarimah another, among the reasons is that the jarimah. qat 'al-tariq always contain the action of the use of force and the ability more so than likely be able to beat anyone who tried to block the action. But do not rule out other forms of jarimah also have the same criteria as the sixth classification above, include the following jarìmah qișās or diyāt dan ta'zìr.
\end{abstract}

Keywords: Islamic Criminal Law, Act 15 of 2003 


\begin{abstract}
ABSTRAK
Tindak pidana terorisme yang dimaksud oleh Undang-undang Nomor 15 Tahun 2003 yaitu segala perbuatan yang memenuhi unsur-unsur tindak pidana yang terdapat dalam undang-undang tersebut. Unsur-unsur tindak pidana yang terdapat dalam bab III ini cukup beragam, namun penulis mengklasifikasikan unsur tindak pidana menjadi enam ditinjau dari bentuk-bentuk tindak pidananya. 1. Secara sengaja menggunakan kekerasan atau ancaman kekerasan. 2.Tindak pidana yang berkaitan dengan penerbangan. 3.Penggunaan senjata atau alat-alat berbahaya lain secara sengaja. 4.Sengaja menyediakan atau mengumpulkan dana demi terlaksananya tindakan terorisme. 5.Sengaja memberikan bantuan, pembantuan, kemudahan, sarana atau keterangan untuk terjadinya tindak pidana terorisme. 6.Permufakatan jahat, percobaan, merencanakan dan/atau menggerakkan orang lain. Permufakatan jahat, percobaan, merencanakan dan/atau menggerakkan orang lain. Ditinjau dari sudut pandang hukum pidana Islam, enam bentuk tindak pidana di atas memiliki banyak kesamaan dengan jarimah qaț' al-țariq jika dibandingkan dengan jarimah-jarimah lain, diantara alasannya yaitu bahwa jarimah qat' al-țariq selalu mengandung aksi penggunaan kekuatan dan kemampuan lebih sehingga besar kemungkinan dapat mengalahkan siapa saja yang mencoba menghalangi aksinya. Namun tidak menutup kemungkinan bentuk jarimah lain juga memiliki kriteria yang sama dengan keenam klasifikasi di atas, jarimah tersebut diantaranya adalah jarīmah qișāṣ atau diyāt dan ta'zīr.
\end{abstract}

Kata Kunci: Hukum Pidana Islam, UU 15 Tahun 2003 


\section{A. PENDAHULUAN}

\section{Latar Belakang Masalah}

Di Indonesia, beberapa peristiwa peledakan bom oleh kalangan teroris masih saja terdengar di beberapa tempat. Penggerebekanpenggerebekan aparat kepolisian terhadap pelaku aksi teror pun sering disaksikan. Sekalipun intensitas penangkapan pelaku teror ini semakin tinggi, para pelaku aksi teror ini seakan tidak pernah lenyap. Semua sepakat aksi terorisme harus diberantas, namun untuk melakukan itu, aparat keamanan tidak bisa bertindak sendirian, diperlukan gerakan nasional terpadu anti terorisme yang berangkat dari kesadaran kolektif. Jelasnya, cara pengamanan dan refresif saja tidak cukup, karena serangan teroris di Indonesia berwatak ideologis. ${ }^{26}$

Indonesia sebagai negara hukum memiliki kewajiban untuk melindungi harkat dan martabat manusia. Demikian pula dalam hal perlindungan warga negara dari tindakan terorisme. Salah satu bentuk perlindungan negara terhadap warganya dari tindakan atau aksi terorisme adalah melalui penegakan hukum, termasuk di dalamnya upaya menciptakan produk hukum yang sesuai. Upaya ini diwujudkan pemerintah dengan mengeluarkan Peraturan Pemerintah Pengganti Undang-Undang Nomor 1 Tahun 2002, yang kemudian disetujui oleh DPR menjadi Undang-undang Nomor 15 Tahun 2003 tentang Pemberantasan Tindak Pidana Terorisme. Diperlukannya undang-undang ini karena pemerintah menyadari tindak pidana terorisme merupakan suatu tindak pidana yang luar biasa sehingga membutuhkan penanganan yang luar biasa juga.

Undang-Undang Nomor 15 Tahun 2003 ini selain mengatur aspek materil juga mengatur aspek formil. Sehingga, undang-undang ini merupakan Undang-undang khusus (lex specialis) dari Kitab Undangundang Hukum Pidana dan Kitab Undang-undang Hukum Acara Pidana.

${ }^{26}$ Hasyim Muzadi, 2010, Terorisme Adalah Musuh Islam, (LPPI) Lembaga Penelitian dan Pengkajian Islam, Jakarta Pusat Indonesia, hlm. 15-16. 
Dengan adanya undang-undang ini diharapkan penyelesaian pidana yang terkait dengan terorisme dari aspek materiil maupun formil dapat segera dilakukan.

Jauh sebelum Undang-undang mengatur tentang tindak pidana Terorisme ada, dalam hukum Islam, peraturan-peraturan terkait kriminalitas, perampasan serta perusakan hak orang lain telah sejak dulu diulas, dipaparkan serta diperdalam oleh para Ulama' lewat karya-karya mereka. Dalam istilah Arab, Teror sering diistilahkan dengan irhāb. Namun persoalan teror ini belum pernah disebutkan secara eksplisit dalam fiqh jināyah (pidana). ${ }^{27}$ Meski begitu bukan berarti tindak kejahatan yang telah dilakukan oleh para teroris itu dapat bebas dari area cakupan hukum Islam. Karena secara umum, tindakan yang dilakukan seperti terorisme, sebenarnya telah diatur sedemikian rupa oleh para Ulama' meski tanpa dilabeli dengan istilah terorisme. seperti pembunuhan baik sengaja atau tidak, perampasan serta perusakan hak milik orang lain seperti harta benda serta keselamatan dan sebagainya.

Kalau ditelusuri lebih dalam lagi, bahwa hukum Islam yang telah banyak terbahas dalam berbagai literatur kitab klasik ternyata banyak kesamaan seperti apa yang terdapat dalam Undang-undang Nomor 15 Tahun 2003 Tentang Pemberantasan Tindak Pidana Terorisme, seperti pembunuhan, pemberontakan, perampasan harta milik orang lain yang dalam hukum Islam di sebut dengan qațl al-'amd, bughāh, hirābah dan sebagainya.

Sampai pada pembahasan ini, kegelisahan penulis pun muncul, terkait sisi muatan hukum Islam Undang-Undang Nomor 15 Tahun 2003 tentang Pemberantasan Tindak Pidana Terorisme mengenai bagaimanakah Undang-undang tersebut jika ditinjau dari sisi hukum Islam.

${ }^{27}$ Abu Yazid, 2005, Fiqh Realitas, Respon Ma'had Aly Terhadap Wacana Hukum Islam kontemporer, Pustaka Pelajar, Yogyakarta, hlm. 71-72. 


\section{Rumusan Masalah}

Bagaimanakah Tinjauan Hukum Pidana Islam (Fiqh Jinayāh) terhadap Pasal 6-19 Undang-Undang Nomor 15 Tahun 2003 tentang Pemberantasan Tindak Pidana Terorisme

\section{Tujuan Penelitian}

Untuk mengkaji secara mendalam tinjauan hukum pidana islam (Fiqh Jinayāh) terhadap Pasal 6-19 Undang-undang Nomor 15 Tahun 2003 tentang Pemberantasan Tindak Pidana Terorisme.

\section{B. PEMBAHASAN}

\section{Bentuk-bentuk Tindak Pidana Terorisme Pasal 6-19 Undang-undang} No. 15 Tahun 2003 Menurut Hukum Pidana Islam

Tindak pidana yang terdapat dalam hukum islam serta tindak pidana terorisme Pasal 6-19 Undang-Undang Nomor 15 Tahun 2003 dengan tujuan agar kegelisahan akademik dalam penelitian ini dapat terjawab, yakni bagaimana Pasal 6-19 dalam Undang-Undang Nomor 15 Tahun 2003 tersebut ditinjau dari hukum islam. Terkait dengan itu, maka dalam bab ini penulis berkeinginan menganalisa mengenai bentuk-bentuk tindak pidana terorisme Pasal 6-19 Undang-Undang Nomor 15 Tahun 2003 dilihat dari kacamata hukum islam.

Seperti dalam pembahsan bab-bab sebelumnya bahwa tindak pidana (jināyah) yang dikenal dalam hukum islam secara umum terbagi menjadi tiga bagian, yakni hudūd, qiṣașạau diyătdan ta'zīr,dan dari ketiga tindak pidana tersebut terbagi lagi menjadi beberapa bagian lagi dilihat dari bentuk-bentuk pidanya. Untuk lebih mudah secara keseluruhan bisa dilihat sebagai berikut:

a. Jarimah Hudūd
1) Jarimah zina
2) Jarimah qadhf
3) Jarimah shurb al-khamr
4) Jarimah sariqoh 
5) Jarimah hirābah atau qaț' al-tāriq

6) Jarimah riddah

7) Jarimah bughāh

b. Jarīmah qișāṣ atau diyāt

1) Pembunuhan secara sengaja (qațl' al-‘amud)

2) Pembunuhan secara tidak sengaja (qațl' al-khāta')

3) Pembunuhan serupa sengaja (qatl shibh al-‘amd)

4) Penganiayaan secara sengaja (jirāhah al-'amd)

5) Penganiayaan secara tidak sengaja (jirāhah al-khāta')

c. Jarihah Ta'zir

Jarihah Ta'zīr yaitu setiap perbuatan kemaksiatan yang menyimpang terhadap perintah Allah yang hukumannya diserahkan kepada kebijakan pemerintah. Sahikh Abi Ishaq mengemukakan tentang ta'zïrini, bahwabarang siapa melakukan kemaksiatan yang tanpa ada ketentuaan hadd atau kafärah, seperti seorang menyentuh perempuan yang bukan mahram-nya (kecuali farji), pencui yang mencuri dibawah kisaran satu niṣāb,atau penuduh zina yang penuduh tersebut bukan pelaku zina atauyang lainnya dari bentuk kemaksiatan maka mereka dijerat dengan hukuman ta'zir menurutpertimbangan pemerintah atau hakim. ${ }^{28}$

Perlu dicermati bahwa dalam pembahasan qat' al-tarīqpada umumnya para 'Ulama' menyertakan pembahasan ta'zimamun terkhusus pada tindakan teror atau menerbakan ketakutan. Jadi jika ada seseorangmelakukan aksi menakut-nakuti yang kemudian mendapat sanksi ta'zir maka mereka bisa disebut dengan qat' al-tariqkarena masuk dalam kriteria yang dimiliki oleh qat' al-tariq yaitu menakut-nakuti saja, membunuh saja,

${ }^{28}$ Al-Shaikh al-Imām Abi Ishaq al-Sayrazi, 2005. al-Muhadhdhab Fi al-Fiqhal-Imām alShafi'I, Beirut, Daral-Fikr.Juz.II, hlm. 404. 
merampas harta benda saja serta membunuh sekaligus merampas harta benda. Secara rinci akan penulis paparkan di bawah.

Dari bentuk-bentuk tindak pidana yang terdapat dalam hukum islam diatas, penulis melihat bahwa tindak pidana dalam hukum Islam yang memiliki banyak kesamaan dengan tindak pidana terorisme yang terdapat dalam Pasal 6-19 UndangUndang Nomor 15 Tahun 2003 adalah tindak pidana hirābah atau bisa disebut dengan qat' al-tariq . penulis mengungkapkan jarimah qat' al-taríqsebagai tindak pidana dalam Pasal 6-19 Undang-Undang Nomor 15 Tahun 2003 dibandingkan dengan tindak pidana hukum islam yang lain karena ditinjau dari definisi, ciri-ciri serta tindakan terorisme dalam pasal-pasal tersebut terdapat banyak sekali kesamaan. Hal ini dapat dilihat dari definisi tentang pemaknaan qat' al-țariq dalam hukum pidana Islam dan pendefinisian terorisme dalam 6-19 UndangUndang Nomor 15 Tahun 2003.

Terkait dengan hal ini, definisi qat' al-tariq yang dikemukakan oleh para pakar hukum islam, diantaranya seperti Shaikh Muhammad al-sharbini dalam kitab beliau, Mughni alMuhtāj. $^{29}$ Beliau mengemukakan bahwa qat' al-țariq secara bahasa sebagai berikut :

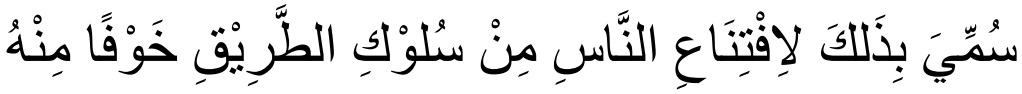 Artinya Dinamakan qàt' al-taríq karena tercegahnya manusia dari berjalan di jalan karena takut padanya.}

Adapun yang dimaksud dengan "jalan" dalam hal ini adalah mencakup tempat yang dapatdipergunakan untuk lewat seprti bangunan dan rumah. Sedangkan secara istilah, Sheikh

\footnotetext{
${ }^{29}$ Muhammad Bin Khatīb al-Sharbinī, Mughnī al-Muhtāj Ilā Mā'rifah Al-fāz Alminhājj,Bairut, Da>r al-Fikr, Juz, IV, hlm. 224.
} 
Shamsuddin Muhammad al-Ramli dalam kitab beliau, Nihāyah al-Muhtāj. ${ }^{30}$ Menyebutkan sebagai berikut :

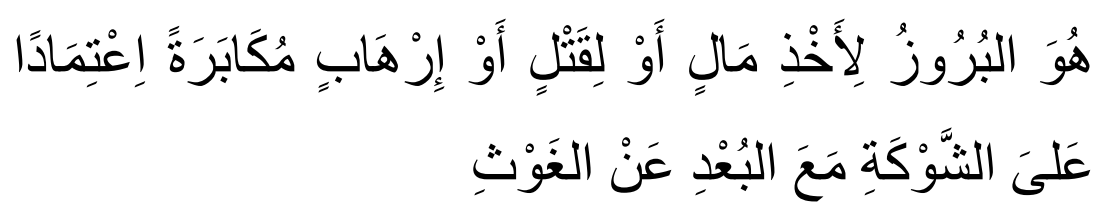

Artinya $q \bar{a} t$, al-taríq ialah tindakan yang secara terangterangan menampakkan diridengan tujuan untuk merampas harta bendaataumembunuh atau memberikan sebuah ketakutan, dengan besar hati, berpegang atas kekuatan serta jauh dari pertolongan.

Dasar hukum qāt' al-tarīq bersumber dari al-Qur'an, yaitu:

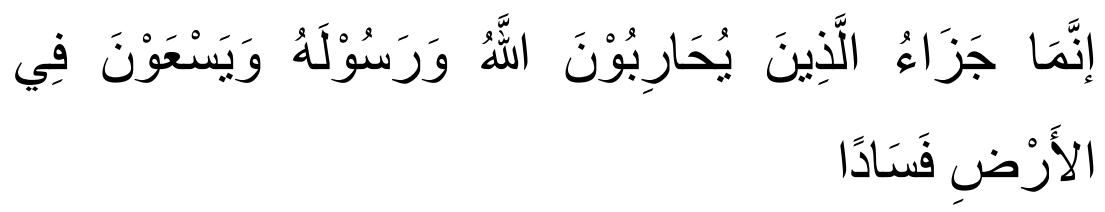

Artinya Sesunggah pembalasan terhadap orang-orang yang memerangi Allah dan Rasul-Nya dan membuat kerusakan di muka bumi. (QS. Al-Maidah: 33)

Para Ulama memberikan sebuah syarat atau batasan bahwa seseorang bisa disebut sebagai pelaku qạt'al-taríq harus memenuhi kriteria sebagai berikut :

a. Orang islam, maka dalam hal ini kafir harbï,kafir mu'ahhad dan kafir musta'man tidak dapat dikategorikan qàt’' al-taríq.

b. Mukallaf,baik laki-laki maupun perempuan serta,

c. Memiliki kekuatan dan kemampuan untuk mengalahkan sekelompok orang (dhū al-shaukah). ${ }^{31}$

\footnotetext{
${ }^{30}$ Sheikh Shamsuddin Muhammad al-Ramli, Nihāyah al-Muhtāj Ila Sharhz alMinhāj,Mesir: Maktabah Mustāfa al-Halbī, Juz. VIII, hlm. 3.

${ }^{31}$ Ibid.,4
} 
Sedangkan terkait dengan situasi dan kondisi, para 'Ulama' jugamemberikan batasan dengan jauhnya pertolongan orang banyak dan pemimpin negara, atau dekat dengan mereka namun tidak mampu menolong korban yang berhadapan dengan qāti' altariq,seperti ketika pelaku masuk rumah dengan membawa senjata dan mencegah penghuninya dari meminta pertolongan. ${ }^{32}$

Para 'Ulama tidak mensyaratkan pelaku qàt' al-tariq harus banyak (baik banyaknya pelaku maupun banyaknya kekuatan dan kemampuan untuk mengalahkan), laki-laki dan tidak pula harus ada persenjataan. Maka jika qat' al-tariq dilakukan oleh satu orang meski perempuan dan memiliki kekuatan lebih dan bisa mengalahkan orang banyak maka pelaku sudah bisa dikatakan sebagai pelaku qat' al-taríq. ${ }^{33}$ Mengenai tindakantindakan yang dapat masuk kategorisasi tindak pidana qat' altarīq dan dapat dikenai hukuman, ada empat macam, seperti yang dijelaskan oleh Imam al-Nawawi di bawah ini, yakni. ${ }^{34}$

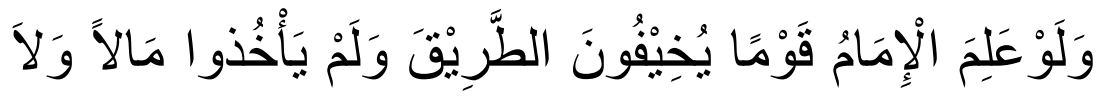

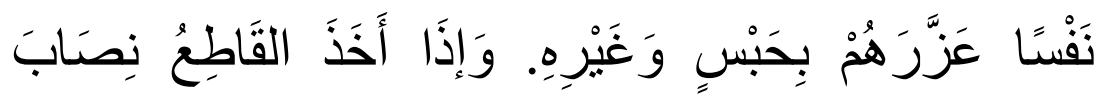

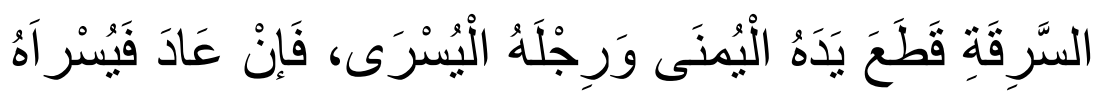

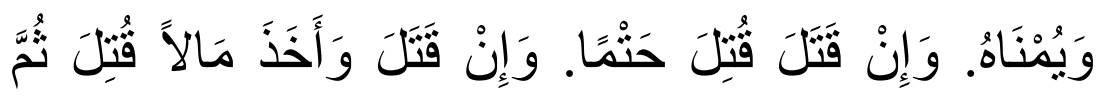

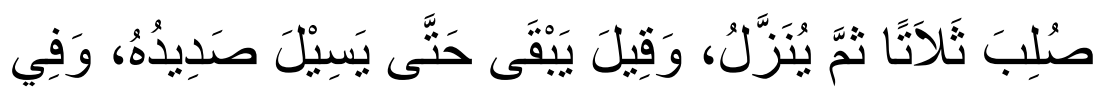

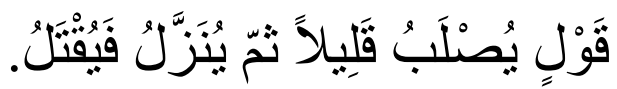

\footnotetext{
${ }^{32}$ Tbid., 6

${ }^{33}$ Ibid., 8 .
}

${ }^{34}$ Abu Zakaria Yahya al-Nawawi, Majmu' Sharh al-Muhadzab, Dar al-Fikr, Beirut, Juz. XVII, hlm. 34. 
Referensi di atas dapat dipahami memiliki empat macam bentuk tindak pidana (jarimah) sebagai berikut:

a. Menebarkan ketakutan dengan tanpa mengambil harta benda dan tidak pula membunuh. Sanksi hukumnya adalah jika pemerintah mengetahui bahwa ada satu orang atau lebih yang melakukan aksi di atas untuk mencari pelaku dan menangkap penebar ketakutan tersebut dengan hukuman ta'zír. ${ }^{35}$ secara wajib kecuali dipandang oleh pemerintah adanya kemashlahatan hukuman ta'zir tersebut adalah dengan dipenjara dan selainnya.

b. Mengambil harta benda saja dengan tanpa membunuh. Sanksi hukum pelaku ini adalah dipotong tangan serta kakinya secara bersilang, yaitu tangan kanan dan kaki kiri, bila masih mengulangi maka sebaliknya yang dipotong adalah tangan kiri dan kaki kanan. Pelaku dapat dikenai sanksi jika pengambilannya mencapai ukuran satu nishab atau lebih.

c. Membunuh dengan tanpa mengambil harta benda. Sanksi hukum pelaku ini adalah wajibnya dibunuh dengan tanpa adanya kewenangan untuk pemaafan bagi keluarga yang bersangkutan dengan korban.

d. Mengambil harta benda disertai dengan pembunuhan. Eksekusi yang ditimpakan untuk pelaku ini adalah dibunuh kemudian disalib.

Karena tingkat kejahatannya berfariasi, maka kadar sanksinya juga bertingkat-tingkat berdasarkan berat ringannya tindakan yang dilakukan oleh pelaku. Jadi jarimah qat' al-taríq hanya terbatas pada empat unsur tindakan saja, sedangkan jika

\footnotetext{
${ }^{35}$ Pada dasarnya tindakan menakut-menakuti atau menggentarkan hati orang lain masuk pada pembahasan jarimah ta'zir namun pada umumnya para ulama' mengelompokkan pembahasan menakut-nakuti atau menggetarkan hati ini kedalam pembahasan jarimah qat' al-tariq.
} 
keluar dari empat unsur di atas berarti masuk dalam kategorisasi tindak pidana yang lain, contoh seperti kawan qat' al-tariq yang satu membunuh orang dan yang lain Cuma menciderai saja, maka tindakan menciderai tersebut masuk pada klasifikasi tindak pidana lain seperti jarīmah qiṣaș, atau diyat, atau yang lainnya karena tidak ditemukan kriteria yang sama dengan keempat tindakan di atas.

Hukuman bagi pelaku yang jumlahnya banyak melakukan pembunuhan terhadap orang banyak maka pelaku tersebut harus dibunuh disebabkan membunuh satu orang saja, sedangkan korban pembunuhan yang lain mendapatkan diyat dari keluarga pelaku sebagai ganti atas terbunuhnya korban. ${ }^{36}$

Adapun yang perlu deketahui bahwa bukan hanya pelaku secara langsung saja yang dapat terkena sanksi hukum namun siapa pun yang berusaha melindungi, membantu atau memuluskan aksi tindak pidana qat' al-taríq seperti mengsuplei senjata yang berbahaya dan lain sebagainya. menurut hukum Islam juga akan mendapatkan sanksi yang setimpal. Jadi siapapun dan apapun tindakan yang telah dilakukan oleh pelaku yang ada hubungannya dengan tindak pidana qat' al-tariq pasti akan mendapat hukuman.

Terkait dengan pengertian tindak pidana terorisme yang termaktub dalam pasal 6-19 Undang-Undang Nomor 15 Tahun 2003 ini. Bahwa tindak pidana yang dapat dikatakan sebagai terorisme adalah segala perbuatan yang memenuhi unsur-unsur yang sesuai dengan ketentuan dalam pasal-pasal dalam undangundang ini, maka perbuatan tersebut dapat dikatakan dengan tindak pidana terorisme, sedangkan bila tidak ada unsur yang sesuai dengan ketentuan yang terdapat dalam undang-undang ini

\footnotetext{
${ }^{36}$ Syamsuddin, Nihayah al-Mihtaj, Juz, VIII, hlm. 9
} 
maka tidak bisa dikatakan dengan tindak pidana terorisme, namun masuk kedalam kategori tindak pidana lain.

Tindak pidana yang memenuhi unsur-unsur yang sesuai dengan ketentuan dalam Pasal 6-19 Undang-Undang Nomor 15 Tahun 2003 dilihat dari bentuk tindak pidananya, penulis klasifikasikan kedalam enam bentuk seperti pada pembahasan bab sebelumnya, namun kali ini penulis sekaligus menganalisis tentang bagaimanakah keenam klasifikasi tersebut jika di tinjau dari perspektif hukum Islam, diantaranya yaitu:

a. Secara sengaja menggunakan kekerasan atau ancaman kekerasan

Tindakan semacam ini baik dimaksudkan maupun tidak bermaksud menimbulkan suasana teror atau rasa takut terhadap orang secara meluas atau menimbulkan korban yang bersifat massal, dengan cara merampas kemerdekaan atau hilangnya nyawa dan harta benda, atau mengakibatkan kerusakan atau kehancuran lingkungan atau fasilitas umum.

Pada bagian ini menggambarkan adanya berbagai bentuk kengerian yang dalam, seperti rasa teror atau hilangnya nyawa karena adanya kekuatan besar yang dapat merusak dan menghancurkan apapun, termasuk sarana publik. Jika hal ini dikaitkan dengan pembahasan jarimah qat' al-tariq, kita dapat menemukan titik temu bahwa pelaku yang hanya menebarkan rasa ketakutan menurut hukum Islam diancam dengan hukum ta'zír dari pemerintah. Yaitu suatu hukuman yang dipergunakan dengan tujuan agar pelaku jera dan bertaubat atas apa yang telah mereka lakukan. 
Sedangkan hukuman bagi pelaku yang mengakibatkan hilangnya nyawa atau adanya korban secara masal adalah dengan hadd dan tertutupnya pintu pemaafan bagi pihak korban atau keluarganya karena adanya unsur yang membedakan antara jarimah-jarimah lain dengan jarimah qat' al-tariq, yaitu adanya kekuatan dan kemampuan besar yang dapat membahayakan siapapun (dhü al-shaukah).

b. Tindak pidana yang berkaitan dengan penerbangan Tindakan ini mencakup segala aspek tindak kejahatan seperti menggagalkan penerbangan, mencelakakan, menghancurkan atau menyebabkan kehancuran, membuat tidak dapat dipakai, merusak bangunan, perampasan, mengusai pesawat terbang, mengakibatkan luka berat seseorang, membahayakan atau tindakan lain yang bersangkutan dengan penerbangan, baik sengaja maupun tidak sengaja, menurut hukum Islam, klasifikasi tindak pidana seperti ini dinilai tidak jauh berbeda dengan pembahasan pada sub pertama diatas, karena yang membedakan hanya pada tata letak tempat atau lokasi saja. Pada bagian pertama menerangkan secara global tanpa ada batasan tempat sedangkan pada bagian kedua ini lebih tertuju pada tindak pidana yang hanya bersangkutan dengan penerbangan.

Sanksinya yaitu jika pelaku hanya menakut-nakuti saja maka pelaku dijerat dengan hukuman ta'zir, dan jika pelaku membunuh dengan tanpa mengambil harta maka wajib baginya dibunuh pula, jika hanya menjalankan aksi perampasan saja maka mereka harus dipotong tangan dan kakinya secara bersilang, jika 
mereka melakukan aksi pembunuhan disertai dengan perampasan maka mereka dibunuh serta disalib, sedangkan jika hanya membuat luka maka pelaku mendapatkan sanksi qiṣaș karena pelaku telah menciderai korban.

c. Penggunaan senjata atau alat-alat berbahaya lain secara sengaja.

Tindakan pada sub ini antara lain memasukkan ke Indonesia, membuat, menerima, mencoba memperoleh, menyerahkan atau mencoba menyerahkan, menguasai, membawa, mempunyai persediaan padanya atau mempunyai dalam miliknya, menyimpan, mengangkut, menyembunyikan, mempergunakan, atau mengeluarkan ke dan/atau dari Indonesia sesuatu senjata api,, amunisi, atau sesuatu bahan peledak dan bahan-bahan lainnya yang berbahaya dengan maksud untuk melakukan tindak pidana terorisme. yang bisa dikatakan dengan senjata di sini adalah seluruh senjata atau alat-alat yang dapat menyebabkan kehancuran serta kerusakan lingkungan yang membahayakan.

Menurut hukum pidana Islam klasifikasi tindak pidana seperti ini masuk seperti halnya pada sub pertama dan kedua di atas, namun yang membedakan hanyalah pemakaian senjata atau alat-alat lain yang dipergunakan melakukan tindak pidana sedangkan pada bagian pertama di atas tidak dijelaskan apakah pelaku menggunakan senjata ataukah tidak. Kesamaan disini jika pelaku menggunakan senjata tersebut untuk melakukan tindakan terorisme, namun jika hanya semacam memberikan senjata, menerima, membawa 
mempunyai dan sebagainya selama tidak menggunakan untuk aksi terorisme maka pelaku dikenai ta'zīr.

d. Sengaja menyediakan atau mengumpulkan dana demi terlaksananya tindakan terorisme.

Pengertian di sini adalah setiap penyediakan atau pengumpulan dana demi terwujudnya tindakan terorisme dapat diancam dengan pidana. Kesengajaan menyediakan atau mengumpulkan dana tersebut sangat berbahaya karena berkat merekalah aksi terorisme dapat terjadi. Tindakan pembantuan tersebut memiliki cakupan yang luas tidak hanya pembantuan dalam segi dana saja namun setiap orang yang memberikan bantuan dalam bentuk apapun yang bertujuan digunakan untuk tindak pidana terorisme akan dijerat dengan undang-undang ini.

Menurut hukum pidana Islam tindakan seperti ini termasuk perbuatan maksiat karena membantu orang yang melakukan tindakan kemaksiatan, yaitu terorisme. Tindakan membantu dalam hal kemaksiatan hukumannya adalah ta'zir karena mereka hanya dalam kapasitas membentuk saja tanpa terjun langsung melakukan tindak pidananya.

e. Sengaja memberikan bantuan, pembantuan, kemudahan, sarana atau keterangan untuk terjadinya tindak pidana terorisme.

Tindakan tersebut antara lain seperti memberikan, meminjamkan uang atau barang atau harta kekayaan lainnya atau menyembunyikan pelaku atau menyembunyikan informasi tentang tindak pidana teroresme dimanapun dan kapanpun pelaku 
melakukannya, baik di dalam wilayah RI maupun di luar wilayah RI. Menurut hukum pidana Islam, tindak pidana seperti ini masuk dalam jarimah ta'zir seperti pada bagian empat di atas. Dengan alasan karena tindakan tersebut merupakan upaya untuk membantu dalam hal maksiat (I'ānah 'Alā al-Ma'ṣiyah) dan tidak ada dalil dalam al-Qur'ān yang menjelaskan tentang ini.

f. Permufakatan jahat, percobaan, merencanakan dan/atau menggerakkan orang lain.

Tindak pidana pada bagian enam ini menurut hukum pidana Islam sama dengan yang ada pada bagian empat dan lima, yaitu sama-sama tidak melakukan tindak pidana secara langsung melainkan hanya bermufakat, percobaan atau menggerakkan saja dan tidak melakukan tindakan secara langsung dilapangan, jadi status mereka hanya membantu dalam hal kemaksiatan saja (i’ānah ala al-ma’ṣiyah). Tindakan mereka dalam hukum pidana Islam adalah ta'zír.

Kalau dicermati, dari keenam bentuk tindak pidana diatas jika dibandingkan dengan jarimah qat' al-tariq, akan dapat ditemukan banyak kesamaan dari keduanya. Salah satunya adalah bentuk tindak pidana terorisme.

Sanksi ta'zir juga dapat dijatuhkan bagi setiap tindak kemaksiatan seperti menyentuh perempuan yang bukan mahramnya atau pembantuan kemaksiatan seperti menyediakan atau mengumpulkan dana, memberikan bantuan, kemudahan, sarana atau keterangan, permufakatan jahat, percobaan, merencanakan dan/atau menggerakkan orang lain demi 
terlaksananya tindak pidana terorisme seperti klasifikasi pada sub 3, 4, sub 5 dan sub 6 di atas.

Sedangkan untuk sub 2, bentuk konsekuensi hukum menurut pidana Islam dapat masuk pada empat bentuk jarīmah qat' al-tarīq di atas, seperti jika pelaku sampai membunuh maka wajib dibunuh juga, jika tidak membunuh namun hanya merampas harta maka wajib dipotong tangan serta kakinya secara bersilang dan sebagainya. Pelaku juga dapat dikenai sanksi qiṣaș atau diyāt bagi pelaku yang tanpa membunuh, tanpa mengambil atau menakut-nakuti namun hanya menciderai anggota tubuh korban saja. Sedangkan bila Merusak harta benda serta sarana milik umum pelaku wajib mengganti harta benda serta sarana yang telah pelaku rusak.

Jadi menurut penulis, tindak pidana dalam hukum Islam yang banyak memiliki kesamaan dengan tindak pidana terorisme pada Pasal 6-19 Undang-Undang Nomor 15 Tahun 2003 adalah qat' al-tariq. Namun untuk mencakup secara keseluruhan enam bentuk tindak pidana Pasal 6-19 tersebut tidak cukup hanya tindak pidana qat' al-taríq saja namun diperlukan juga tindak pidana Islam lain seperti qiṣaș, diyāt atau ta'zîr agar dapat mengakomodir keenam tindak pidana terorisme pada Pasal 6-19 tersebut. 


\section{Subjek Tindak Pidana Terorisme Pasal 6-19 Undang-undang Nomor} 15 Tahun 2003 Serta Sanksi Hukumnya Menurut Hukum Pidana Islam

Setelah melalui analisa perbandingan di atas terkait dengan bentukbentuk jarīmah qat' al-taríq serta jarimah-jarimah lain dan enam bentuk klasifikasi tindak pidana Pasal 6-19 Undang-Undang Nomor 15 Tahun 2003. Maka penulis kali ini bermaksud menganalisa tentang konsekuensi hukum yang dibebankan pada pelaku tindak pidana Pasal 6-19 tersebut menurut tinjaun hukum pidana Islam.

Dari penjelasan sebelumnya bahwa jarimah yang paling dapat mengakomodir tindak pidana terorisme dalam Pasal 6-19 adalah qat' altarīq kecuali bila tidak terdapat unsur yang sama, maka masuk pada jarimah lain seperti qiṣaș atau diyât, atau jarīmah yang lain. Di sini perlu ditekankan bahwa jarimah qat' al-taríq mengandung aksi penggunaan kekuatan dan kemampuan lebih sehingga besar kemungkinan dapat mengalahkan sasaran atau siapa saja yang mencoba menghalangi laju aksi pelaku qat' al-taríq, serta tidak keluar dari empat bentuk tindakan qat' altariq tersebut. Inilah yang membedakan antara jarimah satu ini dengan jarimah-jarimah yang lain.

Tindak pidana yang penulis analisis yaitu enam klasifikasi dalam Pasal 6-19 Undang-Undang Nomor 15 Tahun 2003 dengan memakai kaca mata hukum pidana Islam. Secara rinci dapat dilihat sebagai berikut :

Pertama, pada bagian ini mencakup tindakan secara sengaja menggunakan kekerasan atau ancaman kekerasan yang berujung adanya suasana teror atau rasa takut terhadap orang secara meluas atau menimbulkan korban yang bersifat massal, dengan cara merampas kemerdekaan atau hilangnya nyawa dan harta benda, atau mengakibatkan kerusakan atau kehancuran lingkungan atau fasilitas umum. Menurut saksi dalam undang-undang ini jika pelaku tidak sengaja melakukan tindak pidana ini, dalam artian secara otomatis timbul, maka sanksinya berdasarkan Pasal 6 yaitu dipidana dengan pidana mati atau penjara 
seumur hidup atau pidana penjara paling singkat 4 (empat) tahun dan paling lama 20 (dua puluh) tahun. Namun jika pelaku memang bermaksud dan bertujuan melakukan tindak pidana ini maka sanksi hukumnya berdasarkan Pasal 7, yaitu dipidana dengan pidana penjara paling lama seumur hidup.

Sedangkan sanksi menurut hukum pidana Islam adalah jika pelaku yang hanya memberikan suasana teror atau rasa takut saja, jika pemerintah mengetahui tindakan tersebut wajib menghukum dengan hukuman ta'zïr yaitu dengan penjara dan lain sebagainya tergantung kebijakan pemerintah dalam memberikan konsekuensi hukum. ${ }^{37}$ Sedangkan bagi pelaku yang sampai menghilangkan nyawa maka pelaku harus dibunuh dan tertutupnya pintu pemaafan bagi keluarga. Jika pelaku mengambil harta benda saja, maka ia dipotong tangan dan kakinya secara bersilang, ${ }^{38}$ dan harus mengganti kerusakan dan kerugian korban bila hanya merusak harta milik orang lain atau fasilitas umum.

Kedua, tindak pidana yang berkaitan dengan penerbangan. Tindakan dalam kasus ini mencakup segala aspek tindak kejahatan seperti menggagalkan penerbangan, mencelakakan, menghancurkan, merusak bangunan atau tindakan lain yang bersangkutan dengan penerbangan, maka sanksi hukumnya menurut Pasal 8 sama dengan sanksi hukum yang tercantum pada Pasal 6. Sedangkan menurut hukum pidana Islam kekacauan yang bersangkutan dengan penerbangan tidak berbeda jauh dengan kekacauan yang terjadi selain tentang penerbangan, jadi sanksi hukumnya bisa sama dengan sanksi pada sub pertama di atas.

Ketiga, penggunaan senjata atau alat-alat berbahaya lain secara sengaja. Penggunaan senjata atau alat berbahaya tersebut mengandung pengertian setiap bentuk senjata dan tindakan yang berhubungan dengan persenjataan untuk melakukan aksi terorisme yang membahayakan terhadap keselamatan. Tindakan ini tercantum pada Pasal 9 dan 10. Dalam

\footnotetext{
${ }^{37}$ Al-Syarbini, Mughni al-Muhtaj, Juz, IV: hlm. 226.

${ }^{38}$ Ibid., 230.
} 
Pasal 9 jika pelaku hanya membuat, menerima, mencoba memperoleh, menyerahkan atau mencoba menyerahkan, menguasai, membawa dan tindakan lain dengan maksud digunakan untuk melakukan terorisme maka dipidana dengan pidana mati atau penjara seumur hidup atau pidana penjara paling singkat 3 (tiga) tahun dan paling lama 20 (dua puluh) tahun seperti dalam Pasal 9. Sedangkan pada Pasal 10 jika pelaku menggunakan senjata seperti senjata kimia, senjata biologis, radiologi atau liannya sehingga menimbulkan suasana teror, atau rasa takut terhadap orang secara meluas, atau menimbulkan korban jiwa dan hilangnya harta benda maka pelaku dipidana dengan pidana yang sama sebagaimana pasal 6.

Menurut hukum Islam sanksi tindakan pada Pasal 9 di atas adalah ta'zīr, karena adanya unsur kemaksiatan, ketidaktaatan atau membahayakan bagi kehidupan. Sedangkan sanksi tindak pada Pasal 10 menurut hukum Islam tidak jauh berbeda dengan sanksi yang dijatuhkan pada sub pertama, karena pada dasarnya sama, sedangkan perbedaannya hanya pada penggunaan senjata atau tidaknya dalam melakukan aksi terorisme.

Keempat, senjata menyediakan atau mengumpulkan dana demi terletaknya tindakan terorisme. Pengertian di sini adalah setiap upaya penyediaan atau pengumpulan dana demi terwujudnya tindakan terorisme yang mengancam kehidupan sebagaimana dimaksud dalam Pasal 6, 7, Pasal 8, Pasal 9, dan Pasal 10 atau yang dengan sengaja menyediakan atau mengumpulkan harta kekayaan dengan tujuan akan digunakan atau patut diketahuinya akan digunakan sebagian atau seluruhnya untuk melakukan tindakan seperti menerima, memiliki, menggunakan, menyerahkan, mengubah atau tindakan lain yang mengakibatkan atau dapat mengakibatkan kematian atau luka berat atau menimbulkan kerusakan harta benda dan lain sebagainya. Sanksi dari tindak pidana ini menurut Pasal 11 dan Pasal 12 dipidana dengan pidana penjara paling singkat 3 (tiga) tahun dan paling lama 15 (lima belas) tahun. 
Sedangkan menurut hukum pidana Islam tindakan seperti ini dikenai sanksi hukuman ta'zír karena termasuk membantu dalam hal kemaksiatan, tidak patuh terhadap hukum Allah serta merugikan. Sedangkan sanksi hukum bagi pelaku yang menyebabkan kematian dan rusaknya harta benda dihukum sebagaimana pada sub pertama, yakni hukuman mati secara wajib serta wajib mengganti kerusakan yang diakibatkan oleh pelaku.

Kelima, sengaja memberikan bantuan, pembantuan, kemudahan, sarana atau keterangan untuk terjadinya tindak pidana terorisme. Tindakan tersebut seperti memberikan, meminjamkan uang atau barang atau harta kekayaan lainnya atau menyembunyikan pelaku atau menyembunyikan informasi tentang tindak pidana terorisme. Sanksi yang diancam bagi pelaku yang berada di wilayah RI yaitu dipidana dengan pidana penjara paling singkat 3 (tiga) tahun dan paling lama 15 (lima belas) tahun. Sedangkan pelaku yang berada di luar wilayah RI atau pelaku yang melakukan tindakan pembantuan dikenakan sanksi berupa pidana dengan pidana yang sama sebagai pelaku tindak pidana sebagaimana dimaksud dalam Pasal 6, Pasal 7, Pasal 8, Pasal 9, Pasal 10, Pasal 11, dan Pasal 12.

Keenam, Permufakatan jahat, percobaan, merencanakan dan/atau menggerakkan orang lain demi tercapainya tindak pidana terorisme sebagaimana dimaksudkan dalam Pasal 6, Pasal 7, Pasal 8, Pasal 9, Pasal 10, Pasal 11, dan Pasal 12. Sanksi hukum bagi pelaku yang merencanakan dan/atau menggerakkan orang lain menurut Pasal 14 yaitu dipidana dengan pidana mati atau pidana penjara seumur hidup, serta dipidana dengan pidana yang sama sebagai pelaku tindak pidananya bagi pelaku permufakatan jahat dan percobaan. Lain halnya dengan hukum pidana Islam yang memberikan konsekuensi hukum bagi pelaku tindakan di atas dengan ancaman hukum ta'zir karena tindakan mereka hanya bersifat membantu dibelakang layar saja, dalam arti mereka hanya bermufakat, percobaan serta menggerakkan saja tanpa melakukan tindakan secara langsung dilapangan. 
Terkait dengan masalah subjek hukum dalam Undang-Undang Nomor 15 Tahun 2003 tepatnya pada Pasal 17 dan Pasal 18 yang menjelaskan bahwa korporasi atau badan hukum dapat dikenai sanksi hukum sebab melakukan tindak pidana, menurut hukum pidana Islam, subjek yang mendapatkan sanksi tetaplah pelaku yang bertanggung jawab atas tindakan dirinya sendiri meskipun subjek tersebut ketika melakukan tindakan terorisme memiliki jabatan atau profesi lain ia tetap harus mempertanggungjawabkan perbuatannya sendiri-sendiri serta tidak bisa diwakilkan atau dibebankan pada selain pelaku.

Dalam hal tindak pidana terorisme yang dilakukan oleh atau atas nama suatu korporasi, dalam Pasal 17 dan Pasal 18 dijelaskan bahwa pidana pokok yang dapat dijatuhkan adalah denda paling banyak Rp 1.000.000.000.000,- (satu triliun rupiah). Sedangkan tuntutan dan penjatuhan pidana tersebut dapat dilakukan terhadap korporasi dan/atau pengurusnya. Korporasi (badan hukum) yang terlibat tindak pidana terorisme dapat dibekukan atau dicabut izinnya dan dinyatakan sebagai korporasi yang terlarang. ${ }^{39}$

Ketentuan mengenai penjatuhan pidana minimum khusus sebagaimana dimaksud dalam Pasal 6, Pasal 7, Pasal 8, Pasal 9, Pasal 10, Pasal 11, Pasal 12, Pasal 13, Pasal 15, Pasal 16 dan ketentuan mengenai penjatuhan pidana mati atau pidana penjara seumur hidup sebagaimana dimaksud dalam Pasal 14, tidak berlaku untuk pelaku tindak pidana terorisme yang berusia di bawah 18 (delapan belas) tahun. Dalam hukum pidana Islam, pelaku jarimah qat' al-tariq dibatasi dengan mukallafnya pelaku. Karena itu jika pelaku dalam keadaan belum mukallaf (ghiru altaklif) maka ia belum bisa dikatakan qàt' al-tarīq.

Dalam hukum pidana Islam, pelaku dapat lepas dari jeratan hukum hudud jka pelaku bertaubat, yaitu dengan syarat pelaku taubatnya tersebut sebelum ada penangkapan dari pemerintah, jika taubatnya ketika penangkapan atau bahkan sesudahnya maka hukum baginya harus

\footnotetext{
${ }^{39}$ Undang-Undang Republik Indonesia Nomor 15 Tahun 2003,.
} 
dijatuhkan secara wajib. Sebagaimana yang dijelaskan oleh Syaikh Sulaiman al-Bujairāmi sebagai berikut. ${ }^{40}$

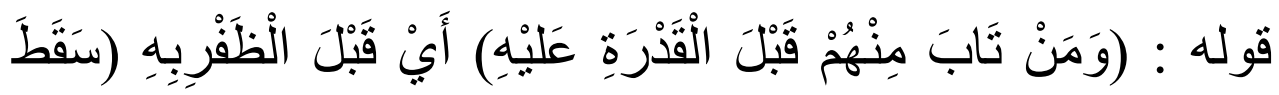

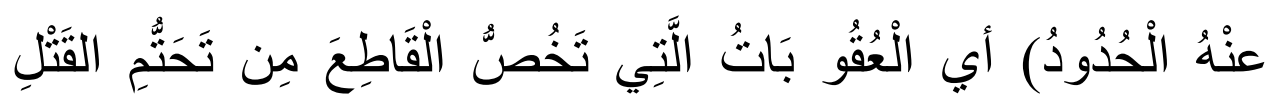

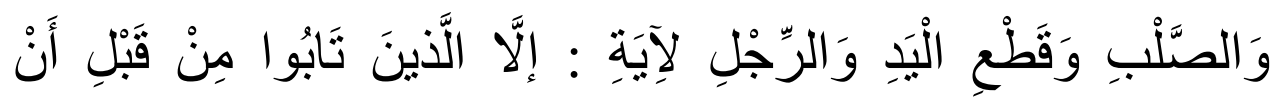
تَقْدِيْرِو ا عَلَنْهُهْ.

Artinya Dan barang siapa yang bertaubat dari mereka ( $q \bar{a} t^{\prime}$ ' al-tari $\bar{q}$ ) sebelum penangkapan terhadap mereka maka gugur bagi mereka hukum hudud, yakni sanksi atau hukuman yang terkhusus bagi al-qāti' (qät’' al-tariq) dari keharusan sanksi bunuh, disalib, dipotong tangan serta kakinya berdasarkan atas ayat: "kecuali mereka yang bertaubat sebelum penangkapan atas mereka".

Firman Allah SWT dalam Al-Qur'an.

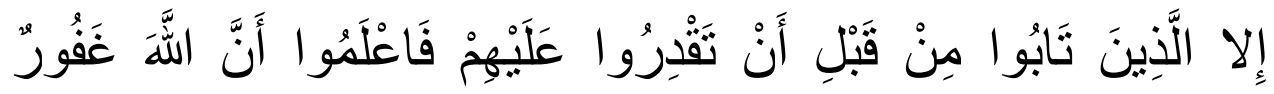

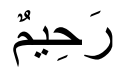

Artinya Kecuali orang-orang yang Taubat (di antara mereka) sebelum kamu dapat menguasai (menangkap) mereka; Maka Ketahuilah bahwasanya Allah Maha Pengampun lagi Maha Penyayang. (QS: Al-Maidah)

${ }^{40}$ Sulaiman Bin Muhammad al-Bujairomi, Hasyiayah al-Bujairami 'ala al-Khatib,. 


\section{PENUTUP}

\section{Kesimpulan}

Ditinjau dari Hukum Pidana Islam (Fiqh Jināyah) terhadap Pasal 619 Undang-undang Nomor 15 Tahun 2003, maka enam bentuk tindak pidana di atas memiliki banyak kesamaan dengan jarīmah qat' al-tariq jika dibandingkan dengan jarimah-jarimmah lain, diantara alasannya yaitu bahwa jarimah qat' al-tariq selalu mengandung aksi penggunaan kekuatan dan kemampuan lebih sehingga besar kemungkinan dapat mengalahkan siapa saja yang mencoba menghalangi aksinya. Namun tidak menutup kemungkinan bentuk jarimah lain juga memiliki kriteria yang sama dengan keenam klasifikasi di atas, jarimah tersebut diantaranya adalah jarìmah qiṣaș atau diyāt dan ta'zìr.

Bentuk tindakan jarimah qat' al-taríq ada empat macam yaitu: pertama, menebarkan ketakutan dengan tanpa mengambil harta benda dan tidak pula membunuh. Kedua, membunuh dengan tanpa mengambil harta benda. Ketiga, mengambil harta benda saja dengan tanpa membunuh. Keempat, mengambil harta benda diserati dengan pembunuhan. Sedangkan untuk syarat pelaku jarimah qat' al-taríq tidak harus banyak (baik banyaknya pelaku maupun banyaknya kekuatan dan kemampuan untuk mengalahkan), laki-laki dan tidak pula harus ada persenjataan. Maka jika qat' al-tariq dilakukan oleh satu orang meskipun perempuan dan memiliki kekuatan lebih dan bisa mengalahkan orang banyak maka pelaku sudah bisa dikatakan sebagai pelaku qat' al-țariq . 


\section{DAFTAR PUSTAKA}

Al-Syarbini, Mughni al-Muhtaj, Juz, IV.

Bujairomi, Sulaiman Bin Muhammad Al, Hasyiayah al-Bujairami 'Ala alKhatib,.

Muzadi, Hasyim, 2010, Terorisme Adalah Musuh Islam, (LPPI) Lembaga Penelitian dan Pengkajian Islam, Jakarta Pusat Indonesia.

Nawawi, Abu Zakaria Yahya Al,Majmu' Sharh al-Muhadzab,Dar al-Fikr, Beirut, Juz. XVII.

Ramli,Sheikh Shamsuddin Muḥammad Al, Nihāyah al-Muhtāj Ila Sharhz alMinhāj, Mesir: Maktabah Mustāfa al-Halbī, Juz. VIII.

Sayrazì, Al-Shaikh al-Imām Abi Ishaq Al, 2005. Al-Muhadhdhab Fi al-FiqhalImām al-Shafi'I, Beirut, Daral-Fikr.

Sharbinī, Muhammad Bin Khatīb Al, Mughnī al-Muhtāj Ilāa Mā'rifah Al-fäz Alminhāj,Bairut, Dār al-Fikr.

Syamsuddin, Nihayah al-Mihtaj.

Undang-Undang Republik Indonesia Nomor 15 Tahun 2003.

Yazid, Abu, 2005, Fiqh Realitas, Respon Ma'had Aly Terhadap Wacana Hukum Islam kontemporer, Pustaka Pelajar, Yogyakarta. 